\title{
Purification of acethylcholinesterase from the mollusc Mytilus galloprovincialis Lam. and investigation of its kinetic properties
}

\author{
Servet DURANAY ${ }^{1 *}\left(\mathbb{D}\right.$, Sezin ANIL ${ }^{2}(\mathbb{D})$, Gözde HASBAL ${ }^{1}$ (D), Nurten ÖZSOY ${ }^{1}$ \\ 1 Department of Biochemistry, Faculty of Pharmacy, İstanbul University, İstanbul, Turkey. \\ 2 Department of Pharmacognosy, Faculty of Pharmacy, İstanbul University, İstanbul, Turkey. \\ * Corresponding Author. E-mail: servetduranay@gmail.com (S.D.); Tel. +90-212-440 00 00/13476.
}

Received: 23 October 2018 / Revised: 12 March 2019 / Accepted: 14 March 2019

\begin{abstract}
The role of acetylcholinesterase in terminating acetylcholine-mediated neurotransmission made it the focus of intense research. In this study the haemolymph Acetylcholinesterase (AChE) from the mollusc Mytilus galloprovincialis was purified to homogeneity by $(\mathrm{NH} 4)_{2} \mathrm{SO}_{4}$ fractional precipitation and affinity chromatography on edrophonium-Sepharose 6B. The enzyme was purified approximatedly 13 fold over the crude extract and was obtained in $3 \%$ yield. The specific activity of purified enzyme was $3 \mathrm{U} / \mathrm{mg}$ protein. It had an optimum $\mathrm{pH}$ of 7.5 and showed optimal activity at $35^{\circ} \mathrm{C}$. Km and Vmax for acetylthiocholine iodide were $1.3 \mathrm{mM}$ and $0.188 \mathrm{mM} / \mathrm{mg} / \mathrm{min}$, respectively. The purified enzyme migrated as a 51000 dalton band during polyacrylamide gel electrophoresis under denaturing and reducing conditions. Three methoxyflavones were examined in order to evaluate their potential as anti-Alzheimer's Disease (AD) agents. All of the compounds were shown to be potent AChE inhibitors. Therefore, these compounds may have great value in the development of therapeutic and preventive agents for AD.
\end{abstract}

KEYWORDS: Acethylcholinesterase; Mytilus galloprovincialis Lam.; enzyme purification; kinetic properties; inhibition by methoxyflavones.

\section{INTRODUCTION}

Acetylcholinesterase (AChE) (acetylcholine acetylhydrolase, EC 3.1.1.7) functions in the central and peripheral nervous systems in the cholinergic neurotransmission by rapidly hydrolysing the neurotransmitter acetylcholine to choline and acetate [1]. In recent years there has been significant progress in the field of AChE research and special attention has been paid to the newly developed purification methods and characterization of AChE, to its possible biological function in the brain, and to its relationship to mental disorders. Much of these researches has been concentrated on gaining an understanding of its remarkable catalytic efficacy, developing therapeutic approaches in the management of Alzheimer's disease and organophosphate intoxication and discovering the new drugs [2].

Many research has been done on the purification of this enzyme from the brain of human [3-4], Japanese quail [5], fishs like Oreochromis aurea [6], Pangasius pangasius [7], electric eel [8-9] and Periophthalmodon schlosseri [10], fetal bovine serum [11], sheep liver [12], mouse [13-14] the head and appendage of Pardosa astrigera L. Koch [15], cotton aphid Aphis gossypii Glover [16], nematodes [17-18], earthworm [19], cotton bollworm [20] and western corn rootworm, Diabrotica virgiferavirgifera [21].

This enzyme has been purified from several sources using conventional chromatographic procedures like DEAE cellulose [6-11-18] ion exchange chromatography, Sephadex G-100 [6] and G-200 [16] gel filtration. Inhibitor ligand affinity chromatography is a powerful technique for the purification of AChE, because of the potent and selective action of the inhibitors such as tacrin [9-12], procainamid [3-16], edrophonium [5-12, 22], $m$-trimetilaminofenilamin [13] and 9-[N-beta-(epsilon-aminocaproil)-beta-aminopropilamino]-akridinium bromid [17]. Sepharose gels served as the affinity matrix and afforded highly purified enzyme preparations. Of the affinity procedures, that employing edrophonium coupled to Sepharose 6B as described by Hodgson and Chubb [23] is effective and reliable and can be used to purify enzyme from a wide range of biological materials.

How to cite this article: Duranay S, Anıl S, Hasbal G, Özsoy N. Purification of acethylcholinesterase from the mollusc Mytilus galloprovincialis Lam. and investigation of its kinetic properties. J Res Pharm. 2019; 23(4): 759-769. 
Although AChE has been previously purified and investigated for certain kinetic characteristics there are still possibilities for further improving purification procedures in order to find a good enzyme source for a commercial and scientific need. Increasing knowledge on the kinetic properties of AChE has greatly increased the prospects of enzyme application as a specific biomarker for pesticide contamination and screening of environmental pollution [6].

Marine system produces richest and inexhaustible source of potential natural products with a nutraceutical and pharmaceutical activity [24]. The phylum Mollusca represents one of the largest and most diverse groups of marine animals. Marine mussels from the Mytilidae family, comprising genera such as Mytilus and Perna, are subject to many investigations for their possible use as a source for bioactive substances such as antimicrobial, anti-inflammatory as well as anti-cancer agents [24-25].

Little is known about the kinetic properties of the enzymes produced by marine organisms and whether or not they would confer technological advances in their use. Mussel hemolymph has also been employed as a target for measuring the alteration of $\mathrm{AChE}$ activity induced by contaminants. Several studies have emphasized AChE inhibition in bivalves such as M. galloprovincialis [26-27] and M. edulis [28] as a biomarker in species exposed to organophosphates, carbamates and some heavy metals.

Pharmacological inhibitors of $\mathrm{AChE}$ are important in controlling diseases that involve impaired acetylcholine-mediated neurotransmission [29]. The use of reversible acetylcholinesterase inhibitors has attracted particular attention for the treatment of Alzheimer's-type dementia and has been the subject of extensive research and clinical investigation [30]. Different classes of plant-derived natural products with AChE-I properties are used for treating symptoms of AD. The most potent AChE-I nowadays appear to be natural or synthetic alkaloids such as galantamine and rivastigmine [31]. Phenolics, the most abundant secondary metabolites of plants, were reported to exhibit neuroprotective effects and act as acetylcholinesterase inhibitors [30]. A limited amount of literatüre data are available on the pharmacological properties of methoxyflavones. Therefore, three of these compounds (hispidulin, 5-hidroxy-,6,7,8' $4^{\prime}$ tetrametoxyflavon and gnafalin) were included in our study. Hispidulin (4',5,7-trihidroxy-6-metoxyflavon) was isolated from Centaurea nerimaniae [32], 5-hidroxy-6,7,3',4'-tetrametoxyflavon was isolated from Artemisia austriaca [33] and gnaphalin (5,7-dihidroxy-3,8-dimetoxyflavon) from Gnaphalium luteo-album L [34].

The aim of this study was to describe the purification of AChE from haemolymph of M. galloprovincialis, a mollusc species existing in the coast of Turkey, employing the affinity chromatography on edrophoniumSepharose 6B. And to examine the inhibitory effects of some methoxyflavones on AChE, which are not so extensively studied previously.

\section{RESULTS AND DISCUSSION}

Mytilus galloprovincialis is the most frequently used organism in Mediterranean marine for monitoring the pollution. The measurement of AChE activity in haemolymph of Mytilus galloprovincialis mollusc is used as a specific biomarker of possible contamination in coastal waters [26].

In the present study we have purified the AChE from haemolymph of the Mytilus galloprovincialis by an efficient two-step procedure of ammonium sulfate precipitation and affinity chromatography on edrophonium-Sepharose 6B.

Ammonium sulphate precipitation proved to be very efficient in removing considerable amounts of other proteins prior to the affinity chromatography. It was found that $\mathrm{AChE}$ could be recovered mainly with a $45 \%$ saturation in the supernatant, which is in accordance with Ma et al. [15] and Du and Dong [19].

The enzyme was purified approximatedly 13 fold over the crude extract and was obtained in $3 \%$ yield. The final specific activity of the purified enzyme was $3 \mathrm{U} / \mathrm{mg}$. The results of purification of AChE from the haemolymph of M. galloprovincialis Lam. are summarized on Table 1.

$\mathrm{AChE}$ is distinguished from other cholinesterases by its sensitivity to certain inhibitors, its relative substrate specificity, and its inhibition by high concentrations of the substrate acetylcholine. The success in the purification of AChE in many tissues depends on the selection of both the substrate and inhibitors [35]. Edrophonium-Sepharose $6 \mathrm{~B}$ affinity chromatography was choosed because of its success in the separation of the AChE activity from other cholinesterases. The matrix which was synthesised by coupling the reversible cholinesterase inhibitor, edrophonium chloride, to epoxy-activated Sepharose had the novel property of selectively binding only one molecular form of acetylcholinesterase [23]. This form of acetylcholinesterase corresponded in molecular size and electrophoretic mobility to the unique form found in cerebrospinal fluid, i.e. secretory acetylcholinesterase $\left(\mathrm{G}_{4} \mathrm{H} \mathrm{AChE}\right)$. It cannot be used to isolate the amphiphilic $\mathrm{AChE}$ variants as 
they fail to be bound by the matrix. Talesa et al. [22] reported that about $80 \%$ of ChE activity of specimens of M. galloprovincialis from distinct marine sites lies in the hemolymph as spontaneously soluble (SS) ChE.

Table 1. Purification of AChE of M. galloprovincialis Lam. from the haemolymph of 40 mussels.

\begin{tabular}{|c|c|c|c|c|c|c|}
\hline Purification step & $\begin{array}{l}\text { Volume } \\
\text { (ml) }\end{array}$ & $\begin{array}{l}\text { Protein } \\
\text { (mg) }\end{array}$ & $\begin{array}{c}\text { Total } \\
\text { activity* }^{*}(\mathrm{U})\end{array}$ & $\begin{array}{l}\text { Specific } \\
\text { activity** } \\
\text { (U/mg) }\end{array}$ & $\begin{array}{c}\text { Recovery } \\
(\%)\end{array}$ & $\begin{array}{c}\text { Purification } \\
\text { fold }\end{array}$ \\
\hline 1. Crude extract & 24 & 21.4 & 5.0 & 0.23 & 100 & 1 \\
\hline $\begin{array}{l}\text { 2. } 45 \% \text { Ammoniun } \\
\text { sulphate fraction }\end{array}$ & 2.5 & 2 & 1.4 & 0.7 & 28 & 3.0 \\
\hline $\begin{array}{l}\text { 3. Edrophonium- } \\
\text { Sepharose } 6 \mathrm{~B} \text { affinity } \\
\text { chromatography }\end{array}$ & 2 & 0.05 & 0.15 & 3 & 3 & 13 \\
\hline
\end{tabular}

Elution of AChE with $10 \mathrm{mM}$ potassium phosphate buffer (pH 7.4) containing $20 \mathrm{mM}$ edrophonium chloride and $0.5 \mathrm{M} \mathrm{NaCl}$ resulted in an apparetly purified enzyme preparation. As can be seen in Figure 1 the affinity chromatography gave three protein containing peaks. The first and second peaks probably coresponds to other cholinesterases which was not bound to the matrix. The highest AChE activity was seen in the third peak, eluted with $10 \mathrm{mM}$ potasium phosphate buffer ( $\mathrm{pH}$ 7.4) containing $20 \mathrm{mM}$ edrophonium chloride and $0.5 \mathrm{M} \mathrm{NaCl}$. This result was in agreement with the reported purification procedure of other AChE's studied so far [5-12].

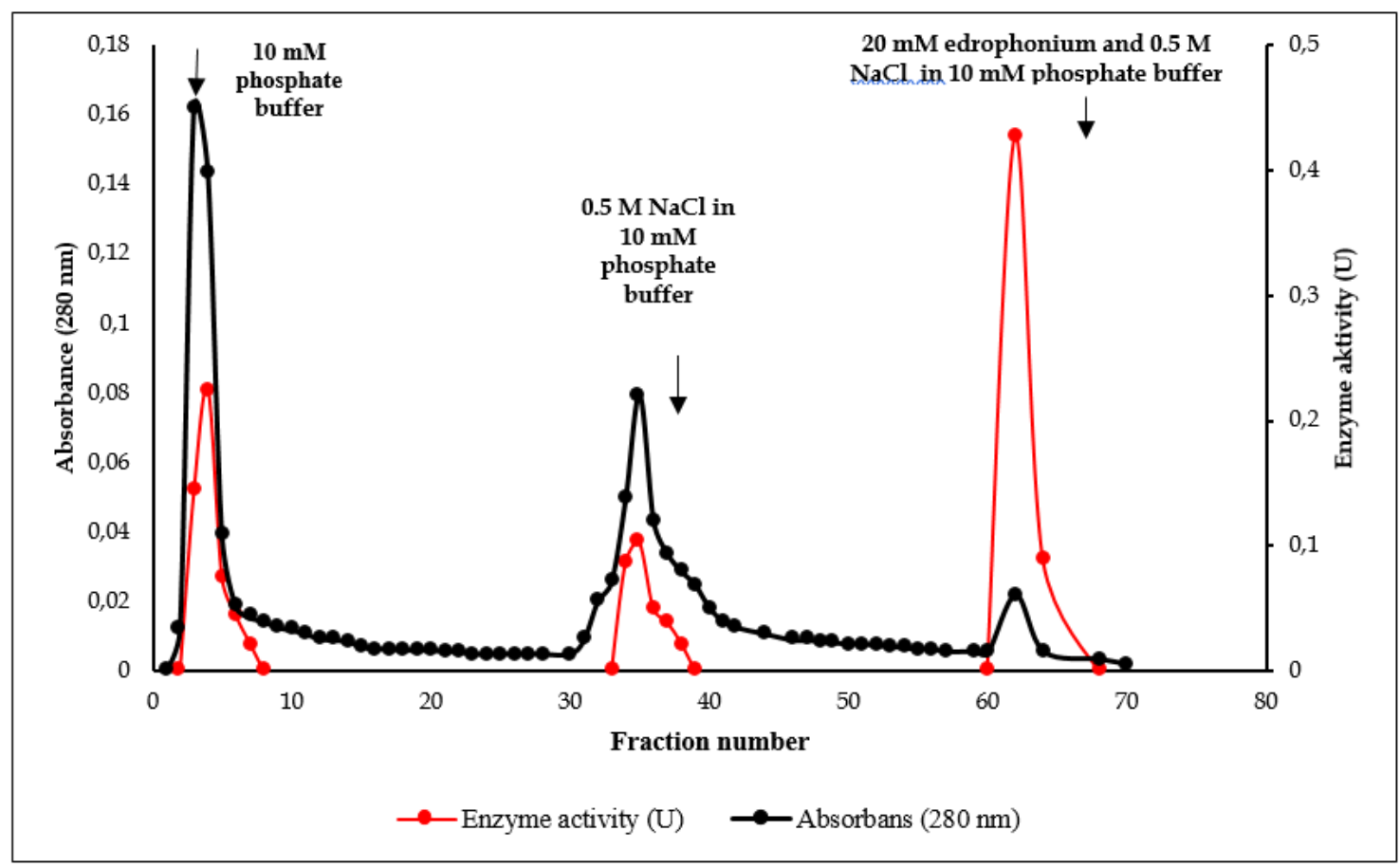

Figure 1. Purification of AChE from haemolymph of the mollusc Mytilus galloprovincialis L. by edrophonium-Sepharose 6B affinity chromatography. Protein elution was monitored at $280 \mathrm{~nm}$. Desalted sample $(2.5 \mathrm{ml})$ containing $2 \mathrm{mg}$ protein precipitated by ammonium sulphate $(45 \%$ salt saturation) was applied onto the column $(1 \times 10 \mathrm{~cm})$ which had been previously pre-equilibrated with $10 \mathrm{mM}$ potassium phosphate buffer ( $\mathrm{pH}$ 7.4). After extensive washing with the same buffer, followed by $10 \mathrm{mM}$ potassium phosphate buffer ( $\mathrm{pH} 7.4$ ) containing $0.5 \mathrm{M} \mathrm{NaCl}$ until the protein content was below 0.01 absorbance at 280 $\mathrm{nm}$, the elution was performed with $10 \mathrm{mM}$ potassium phosphate buffer ( $\mathrm{pH} 7.4$ ) containing $20 \mathrm{mM}$ edrophonium chloride and $0.5 \mathrm{M} \mathrm{NaCl}$. Fractions of $1 \mathrm{ml}$ were collected at a flow rate of $60 \mathrm{ml} / \mathrm{h}$. 
Depending on the source, AChE are known to exibit similarities and differences in properties which include $\mathrm{pH}$ and temperature dependence, molar mass, Michaelis constant $(\mathrm{Km})$, and other physico-chemical parameters.

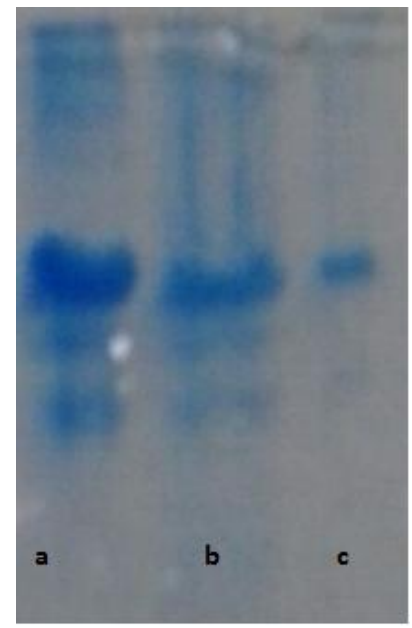

Figure 2. SDS-Polyacrylamide gel electrophoresis of the crude extract, $45 \%$ amonium sulphate fraction and purified AChE after affinity chromatography, from the haemolymph of the mollusc Mytilus galloprovincialis Lam. a. Crude extract, b. $45 \%$ Amonium sulphate fraction, c. Purified AChE after affinity chromatography.

The purified AChE was resolved as a single band by denaturing polyacrylamide electrophoresis. In contrast to previous findings concerning the subunit molecular weight $(68000)$ of highly purified enzyme preparation from the hemolymph of Mytilus galloprovincialis collected in sites of the Adriatic sea [22], in this study the relative molecular mass of purified AChE was estimated to be $51 \mathrm{kDa}$. It was lower than molecular mass reported for Japanese quail brain $(62.5 \mathrm{kDa})$ [5], human brain $(66 \mathrm{kDa})$ [36] and Torpedo californica (71-82 $\mathrm{kDa}$ ) [37], and similar to that of electric organ of the electric eel (25-59 kDa) [38]. SDS-PAGE under reducing conditions is shown in Figure 3.

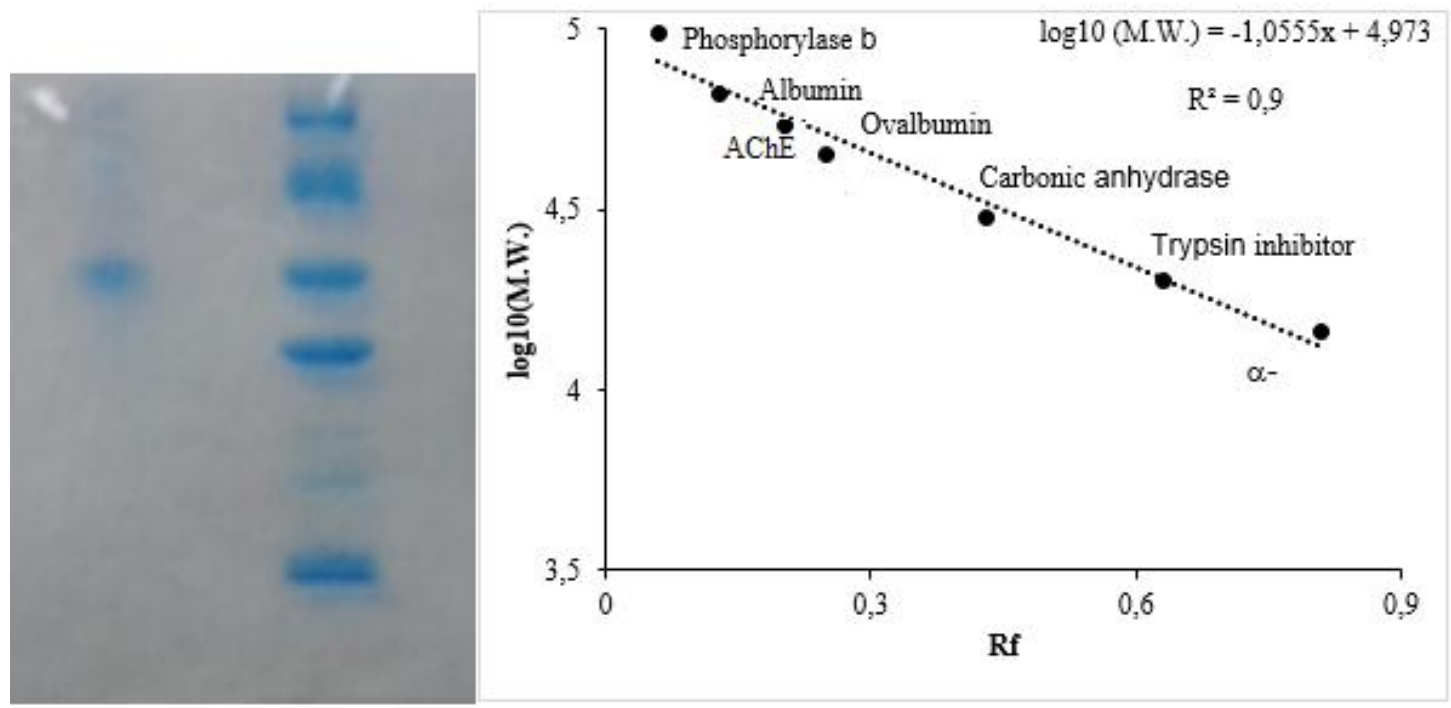

Figure 3. Molecular weight determination based on SDS-polyacrylamide gel electrophoresis under reducing conditions. Standards used were phosphorylase $b\left(M_{r}=97000\right)$, albumin $\left(M_{r}=66000\right)$, ovalbumin $\left(M_{r}=45000\right)$, carbonic anhydrase $\left(\mathrm{M}_{\mathrm{r}}=30000\right)$, trypsin inhibitor $(\mathrm{Mr}=20000)$ and $\alpha$-lactalbumin $\left(\mathrm{M}_{\mathrm{r}}=14400\right)$. 
Optimal activity was observed at $35^{\circ} \mathrm{C}$ (Figure 4), which was similar to that reported for AChE from freshwater fish [6]. The AChE showed a pH optimum at approximately $\mathrm{pH} 7.5$ (Figure 4), which is within the range reported for most invertebrate AChE's.

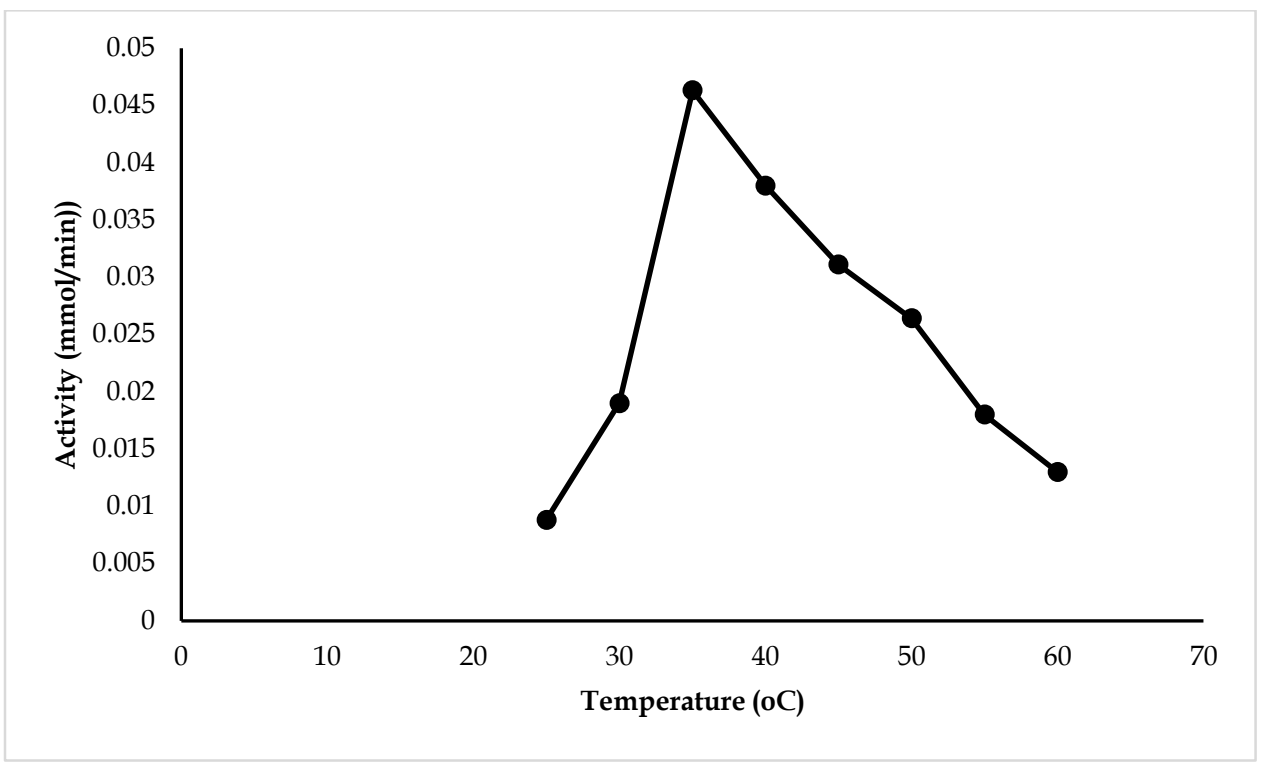

Figure 4. The effect of temerature on the purified AChE from the haemolymph of the mollusc Mytilus galloprovincialis Lam.

The Km and Vmax of the enzyme for ACTI were $1.3 \mathrm{mM}$ and $0.183 \mathrm{mM} / \mathrm{min} / \mathrm{mg}$ (Figure 5, 6).

This value was higher than that reported for AChE from the brain tissues of Oreochromis aurea $(0.183$ $\mathrm{mmol} / \mathrm{L})$ [6], Nebia albiflora muscle $(0.10 \mathrm{mmol} / \mathrm{L})$ [39], brain tissue of Scomberomorus niphonius $(0.311 \mathrm{mmol} / \mathrm{L})$ [36], and Pseudosciaena crocea muscle $(0.125 \mathrm{mmol} / \mathrm{L})$ [40].

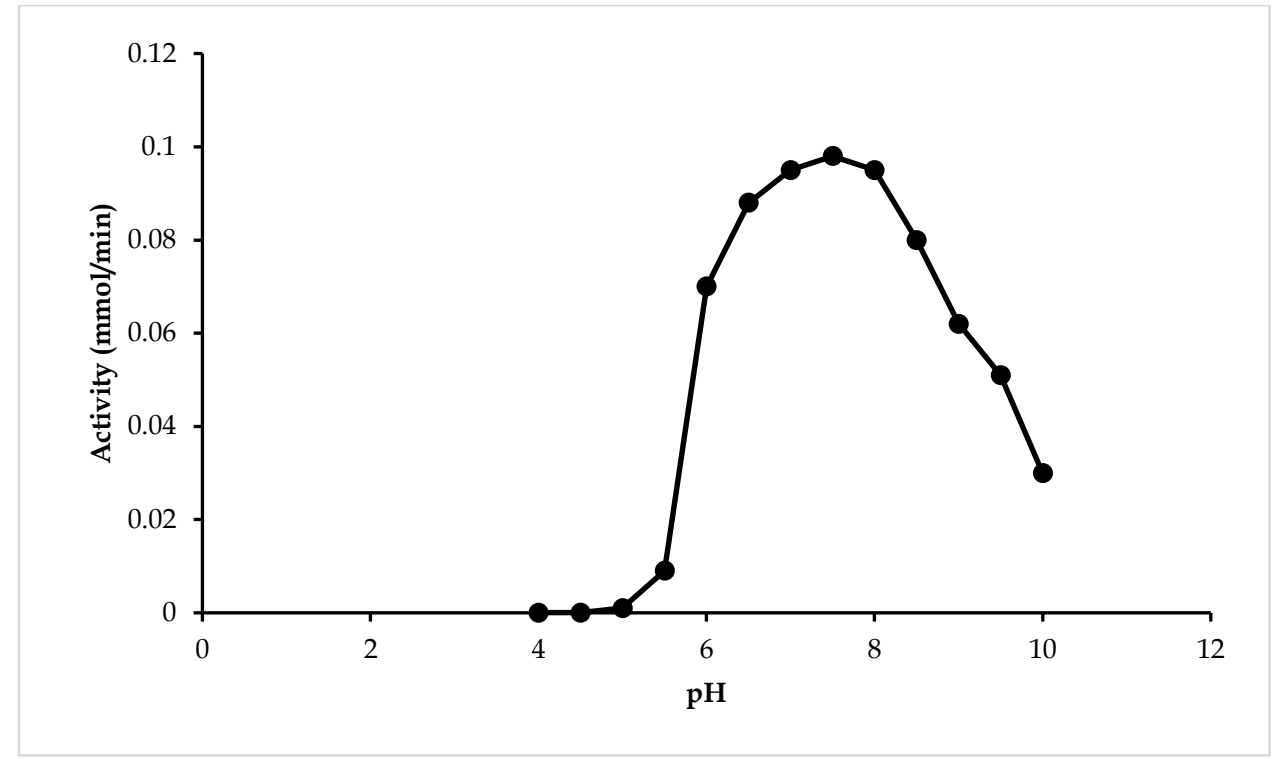

Figure 5. The effect of $\mathrm{pH}$ on the purified $\mathrm{AChE}$ from the haemolymph of the mollusc Mytilus galloprovincialis Lam.

Hispidulin, 5-hidroxy-6,7,3',4'-tetrametoxyflavon and gnaphalin were tested for their in vitro AChE inhibitory activities using galantamine as a positive control. The results obtained with three concentrations of the compounds and expressed as $\mathrm{IC}_{50}$ values, are summarized in Table 2. All the three compunds exhibited potent AChE inhibitory activity, and thus may be beneficial in the treatment of AD. The potency of AChE inhibition was mainly influenced by the number of $-\mathrm{OCH}_{3}$ groups. 5-hidroxy-6,7,3',4'-tetrametoxyflavon with 
three $-\mathrm{OCH}_{3}$ groups was the most potent $\mathrm{AChE}$ inhibitor, while the relatively less potent inhibitors hispidulin (4',5,7-trihidroxy-6-metoxyflavon) and gnaphalin (5,7-dihidroxy-3,8-dimetoxyflavon) have one and two $\mathrm{OCH}_{3}$ groups respectively suggesting the critical role of numbers of methoxy groups in AChE inhibition.

Table 2. Acethylcholinesterase inhibitory activity of hispidulin, 5-hidroxy-6,7,3'4'-tetramethoxyflavon and gnaphalin

\begin{tabular}{lccc}
\hline Substrate & $\mathrm{IC}_{50}(\mu \mathrm{g} / \mathrm{ml})$ & $\mathbf{K}_{\mathbf{i}}(\mu \mathrm{g} / \mathbf{m l})$ & Type of inhibition \\
\hline Hispidulin & $30.17 \pm 2.45^{\mathrm{a}}$ & $28.15 \pm 3.89^{\mathrm{a}}$ & Non-competitive \\
$5-\mathrm{OH}, 6,7,8^{\prime} 4^{\prime}$-tetrametoxyflavon & $10.67 \pm 1.70^{\mathrm{b}}$ & $7.029 \pm 0.84^{\mathrm{b}}$ & Non-competitive \\
Gnaphalin & $13.74 \pm 0.70^{\mathrm{c}}$ & $16.76 \pm 2.72^{\mathrm{c}}$ & Non-competitive \\
Galanthamin & $0.63 \pm 0.09^{\mathrm{d}}$ & $0.2826 \pm 0.02^{\mathrm{d}}$ & Competitive
\end{tabular}

Values were the means of three replicates \pm standard deviation. Values with different letters in the same column were significantly $(p<0.05)$ different.

The inhibition consants were determined from initial velocity measurements at various concentrations of substrate ACTI (10 mM to $0.1 \mathrm{mM})$ and at three different concentrations of metoxyflavones. From the Lineweaver and Burk plot, the common intercept on $1 / \mathrm{V}$ axis indicated that the inhibition of the enzyme by methoxyflavones was of the non-competitive type (Figure 7, 8, 9).

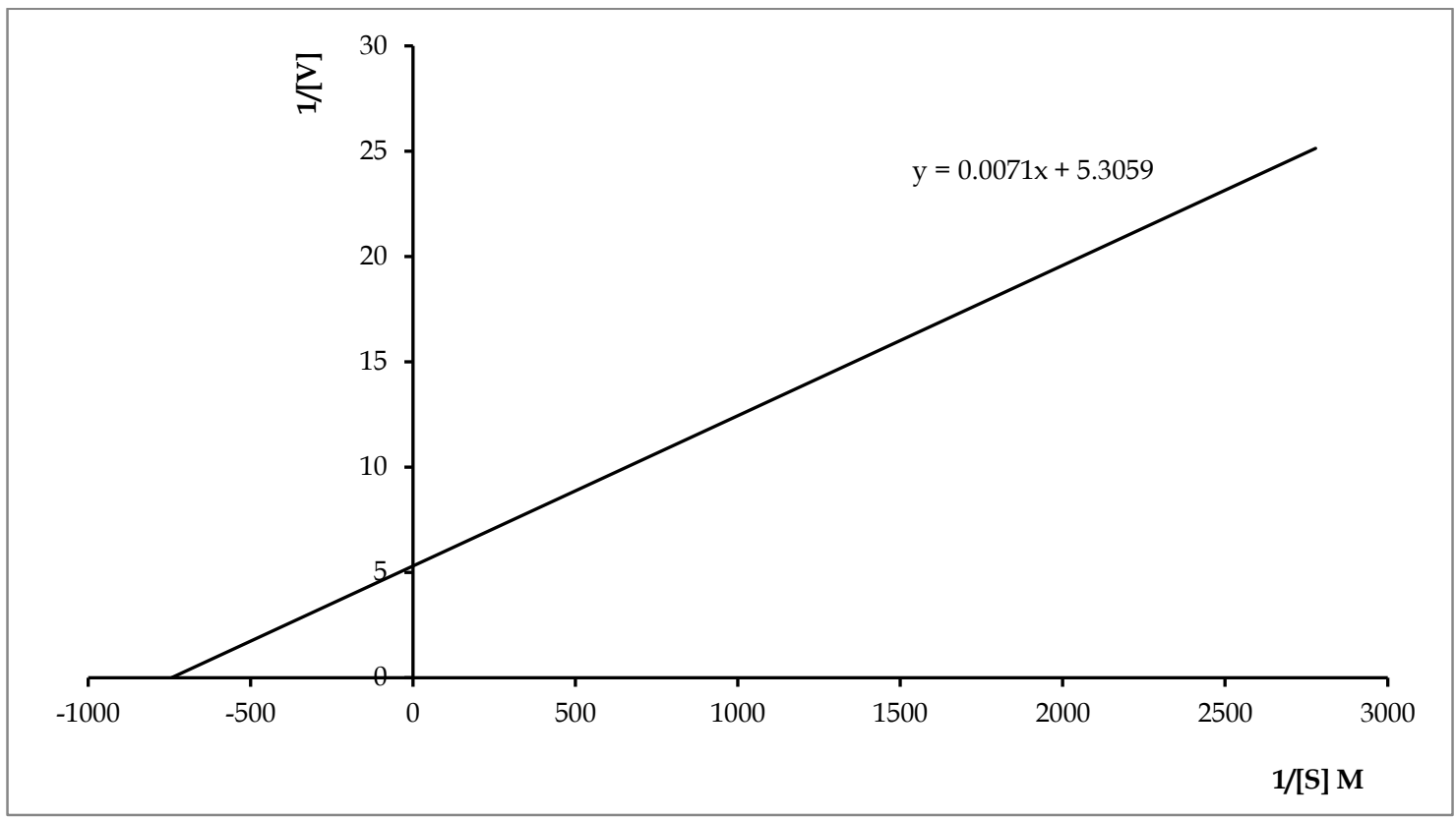

Figure 6. Michaelis constant $(\mathrm{Km})$ of $\mathrm{AChE}$ for acetylthiocholine iodide.

The Ki values obtained for hispidulin, 5-hidroxy-6,7,3'4'-tetrametoxyflavon and gnaphalin were $28.15 \pm$ $3.89,7.029 \pm 0.84$ and $16.76 \pm 2.72 \mu \mathrm{g} / \mathrm{ml}$, respectively (Table 2 ).

Galanthamine acts as a competitive inhibitor of AChE, while hispidulin, 5-hidroxy-6,7,3'4'tetrametoksiflavon and gnaphalin were determined as non-competitive inhibitors. Competitive inhibition takes place by blocking substrate at the active site (tacrine, edrophonium), while non competitive inhibition occurs by binding to the peripheral site (propidium, gallamine) of the enzyme [41]. 


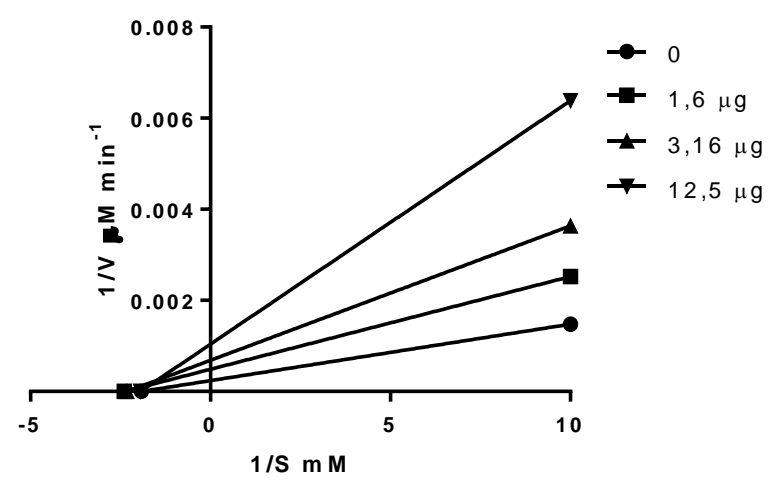

Figure 7. Lineweaver-Burk plot of the inhibitory effect of 5-hidroxy-,6,7,8' $4^{\prime}$-tetrametoxyflavon on AChE.

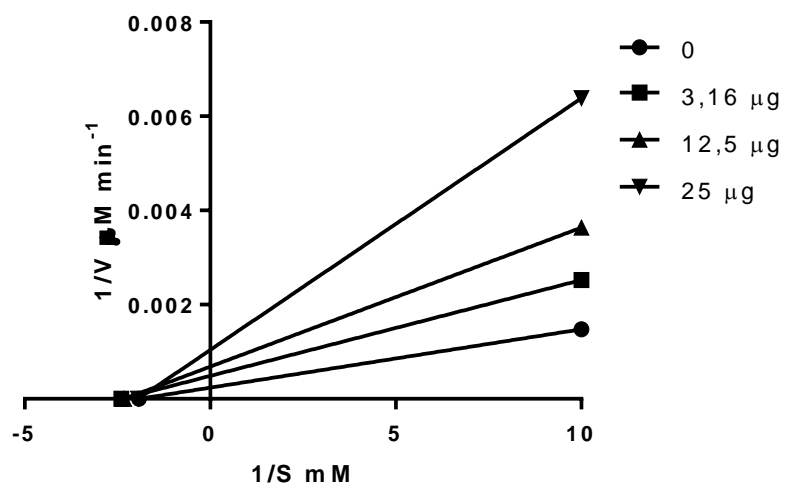

Figure 8. Lineweaver-Burk plot of the inhibitory effect of hispidulin on AChE.

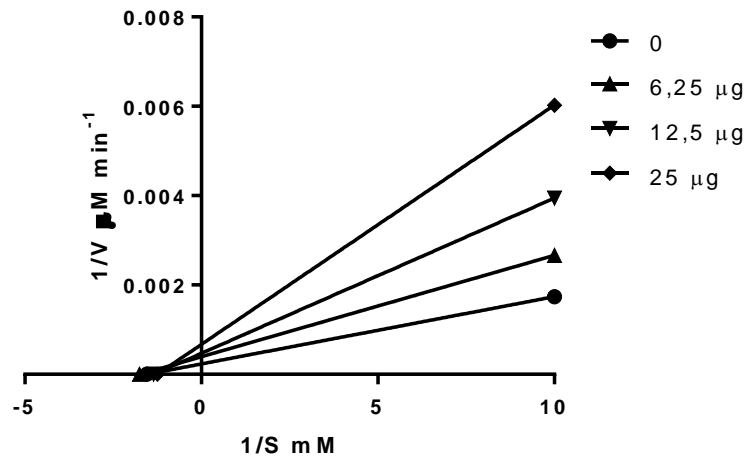

Figure 9. Lineweaver-Burk plot of the inhibitory effect of gnaphalin on AChE.

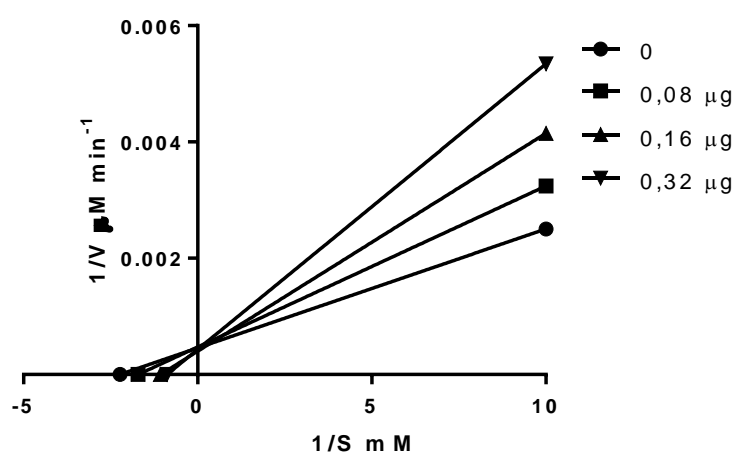

Figure 10. Lineweaver-Burk plot of the inhibitory effect of galanthamin on AChE. 


\section{CONCLUSION}

In this study the usefulness of affinity chromatography for rapidly purifying inhomogeneous enzyme preparations is demonstrated by isolation of haemolymph acethylcholinesterase. The preparation obtained appears to be a homogeneous protein. We have also determined the kinetic parameters of the enzyme purified by the current method.

Three methoxyflavones were examined fort he first time in order to evaluate their potential as anti-AD agents. All of the compounds were shown to be potent AChE inhibitors; in particular, 5-OH,6,7,3'4'tetrametoxyflavon possessed the most potent inhibitory activity. Reversible inhibitors, competitive or noncompetitive, mostly have therapeutic applications and they could be considered for further studies in the treatment of $\mathrm{AD}$.

\section{MATERIALS AND METHODS}

\subsection{Chemicals and materials}

Acetylthiocholine iodide, 5,5'-dithiobis(2-nitrobenzoic acid), edrophonium chloride, epoxy-activated Sepharose 6B, acrylamide, sodium dodecyl sulfate, molecular weight marker proteins were purchased from Sigma Chemical Co. All other chemicals were of the analytical grade.

\subsection{Sample collection}

40 mussels belonging to the species Mytilus galloprovincialis L. were collected from the Yenikapı coastal region of Istanbul.

\subsection{Purification of haemolymph AChE}

\subsubsection{Isolation of haemolymph}

Step 1, Preparation of crude extract:

Using a sterile $1 \mathrm{ml}$ syringe, haemolymph was extracted from the posterior adductor muscle and placed in Eppendorf tubes, than centrifuged at $13000 \mathrm{rpm}$ for 10 minutes at $4^{\circ} \mathrm{C}$. Aliquots of the resulting supernatant were frozen at $-80^{\circ} \mathrm{C}$ until analysis.

Step 2, Ammonium sulphate precipitation:

The supernatant was precipitated with solid ammonium sulphate at $45 \%$ saturation. The precipitate was separated by centrifugation at $13000 \mathrm{rpm}$ for 10 minutes, dissolved in $2 \mathrm{ml}$ of $10 \mathrm{mM}$ potassium phosphate buffer, $\mathrm{pH}$ 7.4, and dialysed against $10 \mathrm{mM}$ potassium phosphate buffer, $\mathrm{pH}$ 7.4. All of these operations were accomplished at $0^{\circ}-4^{\circ} \mathrm{C}$.

Step 3, Affinity chromatography:

Edrophonium-Sepharose 6B affinity gel was prepared as described by Son et al. [5].

The $45 \% \mathrm{NH}_{4} \mathrm{SO}_{4}$ fraction containing $2 \mathrm{mg}$ protein was applied to the affinity column $(1 \times 11 \mathrm{~cm})$. After extensive washing with $10 \mathrm{mM}$ potassium phosphate buffer ( $\mathrm{pH}$ 7.4), followed by $10 \mathrm{mM}$ potasium phosphate buffer ( $\mathrm{pH} 7.4$ ) containing $0.5 \mathrm{M} \mathrm{NaCl}$ until the protein content was below 0.01 absorbance at $280 \mathrm{~nm}$, the enzyme was eluted with $10 \mathrm{mM}$ potasium phosphate buffer ( $\mathrm{pH}$ 7.4) containing $20 \mathrm{mM}$ edrophonium chloride and $0.5 \mathrm{M} \mathrm{NaCl}$. The flow rates throughout the experiments were $60 \mathrm{ml} / \mathrm{h}$.

The eluates was collected in $1 \mathrm{ml}$ fractions and assayed for protein content at $280 \mathrm{~nm}$ and enzyme activity, those containing AChE activity were pooled and concentrated by ultrafiltration with a stirred cell (model; Amicon, Inc., Beverly, Mass.) equipped with a PM 10 membrane under nitrogen pressure of $20 \mathrm{lb} / \mathrm{in}^{2}$. After dialysis against $10 \mathrm{mM}$ potassium phosphate buffer $(\mathrm{pH} 7.4)$ the preparation was used in enzyme characterization experiments.

\subsection{Determination of protein content}

Protein concentration was determined either by the Bradford method [42] using BSA as a standard or measurement of absorbance at $280 \mathrm{~nm}$.

Five dilutions of protein standard $(128 \mu \mathrm{g} / \mathrm{ml})$, which covered the linear range from 8 to $64 \mu \mathrm{g} / \mathrm{ml}$ were prepared. $100 \mu \mathrm{l}$ of each standard or sample solution were pipette into separate microplate wells. $150 \mu \mathrm{l}$ of dye reagent concentrate were subsequently added to each well. The samples and reagent were mixed thoroughly using a microplate mixer and incubated at room temperature for 10 minutes. The absorbance was read at $595 \mathrm{~nm}$ using a multiplate ELISA reader (BioTek Eon) within one hour of the assay. 


\subsection{Enzyme activity}

The samples were screened for their AChE inhibitory activity through the modified Ellman's spectrophotometric method [43]. Briefly, $100 \mathrm{mM}$ sodium phosphate buffer at $\mathrm{pH} 7.5$ containing $1.5 \mathrm{mg}$ $\mathrm{NaH}_{2} \mathrm{CO}_{4}, 75 \mathrm{mM}$ acetylthiocholine iodide and $10 \mathrm{mM}$ DTNB $(3.96 \mathrm{mg} / \mathrm{ml})$ in $100 \mathrm{mM}$ sodium phosphate buffer was mixed at a ratio of 150: 2: 5 to give final concentrations of $1 \mathrm{mM}$ for acetylthiocholine iodide and $0.3 \mathrm{mM}$ for DTNB. $50 \mu \mathrm{l}$ of the samples and $10 \mathrm{mM}$ potassium phosphate buffer, $\mathrm{pH} 7.4$ were transferred to the experimental and blank wells, respectively, in a 96 well microplate. $250 \mu \mathrm{l}$ of the Ellmans assay solution were pipette to all the wells. The increase in absorbance of the produced yellow 5-thio-2-nitrobenzoate was measured at $412 \mathrm{~nm}$ every minute for $10 \mathrm{~min}$ using a microplate reader (Biotek, Winooski, VT, USA). Any increase in absorbance due to the spontaneous hydrolysis of substrate was corrected by subtracting the rate of the reaction before adding the enzyme from the rate after adding the enzyme. Enzyme activity was expressed as $\mu \mathrm{mol} / \mathrm{min} / \mathrm{ml}$ of formation of TNB by using extinction coefficient of $13.6 \mathrm{mM}^{-1} \mathrm{~cm}^{-1}$.

\subsection{Electrophoresis}

Polyacrylamide gel (10\%) was used to determine the apparant molecular weight $(\mathrm{Mr})$ and the degree of purity of the acethylcholinesterase.

\subsection{Subunit molar mass determination}

SDS-polyacrylamide gel electrophoresis followed the method of Laemmli [44], modified with $4 \%$ polyacrilamide stacking gel in $0.125 \mathrm{~mol} / \mathrm{L}$ Tris- $\mathrm{HCl}$ buffer, $\mathrm{pH} 6.8$, with $0.1 \% \mathrm{SDS}$ and $10 \%$ polyacrilamide separating gradient gel in $0.25 \mathrm{~mol} / \mathrm{L}$ Tris- $\mathrm{HCl}$ buffer, $\mathrm{pH}$ 8.8, with $0.1 \%$ SDS. The electrophoresis buffer consisted of $0.05 \mathrm{~mol} / \mathrm{L}$ Tris, $0.192 \mathrm{~mol} / \mathrm{L}$ glycine, $\mathrm{pH} 8.3$, with $0.1 \%$ SDS. Subunit molar mass was analysed under reduced conditions. Before application to the gel the samples were boiled for $90 \mathrm{~s}$ with sample buffer containing $0.125 \mathrm{~mol} / \mathrm{L}$ Tris-HCl, $\mathrm{pH} 6.8,2 \% \mathrm{SDS}, 10 \%$ glycerol, $0.02 \%$ bromphenol and $5 \%$ 2-mercaptoethanol at a ratio $1: 1$. After a run at $5 \mathrm{~mA} /$ gel at room temperature, the gels were stained overnight with $0.2 \%$ Coomassie Brilliant Blue R 250 in $45: 45: 10$ (methanol : water : acetic acid). The destaining mixture contained $10 \mathrm{ml}$ of acetic acid, $25 \mathrm{ml}$ of methanol and $65 \mathrm{ml}$ of water.

\subsection{Kinetic studies}

\subsubsection{Effect of $p H$ on enzyme activity}

The $\mathrm{pH}$ optimum was determined performing the assay in the $\mathrm{pH}$ range of 3.0-7.0 potassium phosphate buffer and $\mathrm{pH}$ range of 8.0-9.0 using Tris- $\mathrm{HCl}$ buffer.

\subsubsection{Effect of temperature on enzyme activity}

The enzyme activity was measured in the range of $10-70^{\circ} \mathrm{C}$ using the standard activity assay procedure at related temperature.

\subsubsection{Substrat specificity}

To determine the substrate specificity of the enzyme, we assayed the hydrolysis of the substrate acetylthiocholine iodide. The Michaelis constant value $(\mathrm{Km})$ was determined at concentrations ranging from 0.1 to $10 \mathrm{mM}$.

\subsection{Inhibition of AChE by 5-hydroxy-6,7,8'4'-tetrametoksiflavon, hispudiline and gnaphaline}

In order to elucidate the type of inhibition of the compounds, the enzyme activity was measured in the presence of an increasing concentrations of ACTI $(0.1 \mathrm{M}-0.01 \mathrm{M})$, and in the presence or absence of four concentrations of hispidulin, 5-hydroxy-6,7,8'4'-tetrametoksiflavon and gnaphaline (final 1,6; 3,16; 12,5 and 25 $\mu \mathrm{g} / \mathrm{ml}$ ). Incubation of enzyme preparation with methoxyflavones for 30 minutes was performed prior to determination of residual activities.

Determination of enzyme kinetic parameters was perform using GraphPad Prism version 7.00. The kinetic constant $\mathrm{Km}$ and Vmax were determined by double-reciprocal Lineweaver-Burk plot analysis of the data.

\subsection{Statistical analysis}

All measurements were made in triplicate. The results were statistically analyzed using GraphPad Prism version 7.00. Results were considered significant at $p<0.05$. 
Acknowledgements: This work is a part of Servet Duranay's Master Thesis and was supported by the Research Fund of İstanbul University: Project Number: 21244.

Author contributions: Concept - N.O., S.D.; Design - N.O., S.D.; Supervision - N.O.; Resource - N.O.; Materials - S.A., G.H.; Data Collection \&/or Processing - N.O., S.D., S.A., G.H.; Analysis \&/or Interpretation - N.O., S.D.; Literature Search - N.O., S.D.; Writing - N.O., S.D.; Critical Reviews - N.O., S.D., S.A., G.H.

Conflict of interest statement: The authors declared no conflict of interest.

\section{REFERENCES}

[1] Ramesh B, Rajesh B, Bhargav PRK, Devi NV. Study of acetylcholinesterase (ache) gene expression and its relation with RNA content in brain of five different vertebrate species. J Biotechnol Biochem. 2018; 4(2): 21-40. [CrossRef]

[2] Sussman JL, Silman I. Acetylcholinesterase: structure and use as a model for specific cation-protein interactions. Curr Opin Struct Biol. 1992; 2: 721-729. [CrossRef]

[3] Novales LP. Comparison of standard chromatographic procedures for the optimal purification of soluble human brain acetylcholinesterase. Biomed Chromatogr. 1994; 8: 259-266. [CrossRef]

[4] Kaya HB, Özcan B, Şişecioğlu M, Özdemir H. Purification of acetylcholinesterase by 9-amino-1,2,3,4tetrahydroacridine from human erythrocytes. Appl Biochem Biotechnol. 2013; 170: 198-209. [CrossRef]

[5] Son JY, Shin S, Choi KH, Park IK. Purification of soluble acetylcholinesterase from Japanese quail brain by affinity chromatography. Int J Biochem Cell Biol. 2002; 34: 204-210. [CrossRef]

[6] Ding YH, Wu XM, Fang JB. Purification and characterization of acetylcholinesterase from brain tissues of Oreochromis aurea and its application in environmental pesticide monitoring. Sci Cold Arid Reg. 2011; 3: 339-343.

[7] Tham LG, Halmi MIE, Sharif MSA, Perumal N, Begum C, Syed MA, Shukor MY. Sensitivity of crude and partially purified acethylcholinesterase from fish to carbamates and organophosphates. J Environ Biol. 2014; 35: 285-287.

[8] Berman JD, Young M. Rapid and complete purification of acetylcholinesterases of electric eel and erythrocyte by affinity chromatography. Proc Natl Acad Sci USA. 1971; 68: 395-398. [CrossRef]

[9] Carroll RT, Grimm JL, Hepburn TW, Emmerling MR. Purification of acetylcholinesterase by tacrine affinity chromatography. Protein Expr Purif. 1995; 6: 389-393. [CrossRef]

[10] Sabullah MK, Sulaiman MR, Shukor MS, Yusof MT, Johari WLW, Shukor MY, Syahir A. Heavy metals biomonitoring via inhibitive assay of acetylcholinesterase from Periophthalmodon schlosseri. Rend Lincei. 2015; 26: 151-158. [CrossRef]

[11] Ralston JS, Rush RS, Doctor PB, Wolfe D. Acetylcholines from fetal bovine serum. J Biol Chem. 1985; 260: $4312-4318$.

[12] Askar KA, Kudi AC, Moody AJ. Purification of soluble acetylcholinesterase from sheep liver by affinity chromatography. Appl Biochem Biotechnol. 2011; 165: 336-346. [CrossRef]

[13] Marchot P, Ravelli RBG, Raves ML, Bourne Y, Vellom DC, Kanter J, Sussman JL, Taylor P. Soluble monomeric acetylcholinesterase from mouse: expression, purification and crystallization in complex with fasciculin. Protein Sci. 1996; 5: 672-679. [CrossRef]

[14] Gomez JL, Nieto-Cerón S, Campoy FJ, Muñoz-Delgado E, Vidal CJ. Purification and properties of hydrophilic dimers of acetylcholinesterase from mouse erythrocytes. Int J Biochem Cell Biol. 2003; 35: 1109-1118. [CrossRef]

[15] Ma M, Zhang B, Li S-C. Purification and partial characterization of acetylcholinesterase from Pardosa astrigera L. Koch. J Cell Anim Biol. 2011; 5: 11-16.

[16] Li F, Han Z. Purification and characterization of acetylcholinesterase from cotton aphid (Aphis gossypii Glover). Arch Insect Biochem Physiol. 2002; 51: 37-45. [CrossRef]

[17] Griggs ME, Tang L, Hussein AS, Selkirk ME. Purification and properties of monomeric (G1) forms of acetylcholinesterase secreted by Nippostrongylus brasiliensis. Mol Biochem Parasitol. 1997; 90: 513-524. [CrossRef]

[18] Mohamed MA, Mahdy EME, Ghazy AM. The activity of detoxifying enzymes in the infective juveniles of Heterorhabditis bacteriophora strains: Purification and characterization of two acetylcholinesterases. Comp Biochem Physiol C. 2016; 180: 11-22. [CrossRef]

[19] Du ZH, Dong SJ. Purification of cholinesterase of earthworm by affinity chromatography. Bull Acad Military Med Sci. 1986; 1: 28-32.

[20] Gao XW, Zhou XG, Wang RJ, Zheng BZ. Distribution and purification of acetylcholinesterase in cotton bollworm (Lepidoptera: Noctuidae). Acta Entomol Sin. 1998; 41: 21-25. 
[21] Gao JR, Rao JV, Wilde GE, Zhu KY. Purification and kinetic analysis of acetylcholinesterase from western corn rootworm, Diabrotica virgifera virgifera (Coleoptera: Chrysomelidae). Arch Insect Biochem Physiol. 1998; 39: 118-125. [CrossRef]

[22] Talesa V, Romani R, Antognelli C, Giovannini E, Rosi G. Soluble and membrane-bound acetylcholinesterases in Mytilus galloprovincialis (Pelecypoda: Filibranchia) from the northern Adriatic sea. Chem Biol Interact. 2001; 134(2): 151-166. [CrossRef]

[23] Hodgson AJ, Chubb IW. Isolation of the secretory form of soluble acetylcholinesterase by using affinity chromatography on edrophonium-Sepharose. J Neurochem. 1983; 41: 654-662. [CrossRef]

[24] Grienke U, Silke J, Tasdemir D. Bioactive compounds from marine mussels and their effects on human health. Food Chem. 2014; 142: 48-60. [CrossRef]

[25] Scotti PD, Dearing SC, Greenwood DR, Newcomb RD. Pernin: A novel, self-aggregating haemolymph protein from the New Zealand green-lipped mussel, Perna canaliculus (Bivalvia: Mytilidae). Comp Biochem Physiol B. 2001; 128: 767-779. [CrossRef]

[26] Moreira SM, Coimbra J, Guilhermino L. Acetylcholinesterase of Mytilus galloprovincialis LmK. hemolymph: A suitable environmental biomarker. Bull Environ Contam Toxicol. 2001; 67: 470-475. [CrossRef]

[27] Taleb ZM, Benghali S, Kaddour A, Boutiba Z. Monitoring the biological effects of pollution on the Algerian west coast using mussels Mytilus galloprovincialis. Oceanologia. 2007; 49(4): 543-564.

[28] Yaqin H, Hansen PD. The use of cholinergic biomarker, cholinesterase activity of blue mussel Mytilus edulis to detect the effects of organophosphorous pesticides. Afr J Biochem Res. 2010; 4(12): 265-272. [CrossRef]

[29] Khanam H, Ali A, Asif M, Shamsuzzaman. Neurodegenerative diseases linked to misfolded proteins and their therapeutic approaches: A review. Eur J Med Chem. 2016; 124: 1121-1141. [CrossRef]

[30] Roseiro LB, Rauter AP, Serralheiro MLM. Polyphenols as acetylcholinesterase inhibitors: Structural specificity and impact on human disease. Nutr Aging. 2012; 1: 99-111. [CrossRef]

[31] Dall'Acqua S. Plant-derived acetylcholinesterase inhibitory alkaloids for the treatment of Alzheimer's disease. Bot: Targets Ther. 2013; 3: 19-28. [CrossRef]

[32] Melikoglu G, Erbay MS, Anıl S, Kultur S. Flavonoids of Centaurea nerimaniae S. Kultur. 3. rd International Multidisciplinary Symposium on Drug Research and Development - DRD. Abstract Book. Kayseri, Turkey, 2017, p.135.

[33] Cubukcu B, Melikoglu G. Flavonoids of Artemisia austriaca. Planta Med. 1996; 61 (5): 488-499. [CrossRef]

[34] Mericli AH. Flavonoids from Gnaphalium luteo-album L. J Fac Pharm Istanbul Univ. 1980; 16: 84-87. [CrossRef]

[35] Hodgson AJ, Chubb IW. A method for the detection and quantitation of secretory acetylcholinesterase. Neurochem Pathol. 1983; 1: 212-218. [CrossRef]

[36] Zhu M, Xin Y, Sun M, Fang Y. Purification and properties of acetylcholinesterase from human brain. Life Sci Earth Sci. 1993; 10: 1207-1215.

[37] Lwebuga-Mukasa JS, Lappi S, Taylor P. Molecular forms of acetylcholinesterase from Torpedo californica: Their relation to synaptic membranes. Biochemistry. 1976; 15: 1425-1434. [CrossRef]

[38] Dudai Y, Silman I. The molecular weight and subunit structure of acetylcholinesterase preparations from the electric organ of the electric EEL. Biochem Biophys Res Commun. 1974; 59: 117-124. [CrossRef]

[39] Shi SP, Zhang JY. Purification and some properties of cholinesterase from Nebia albiflora muscle. Acta Biochim Biophys Sin. 1981; 13(1): 10-16.

[40] Dong ZH. Purification of cholinesterase from Pseudosciaena crocea muscle. Chin Biochem J. 1995; 11(4): 487-489.

[41] Patočka J, Kuča K, Jun D. Acetylcholinesterase and butyrylcholinesterase- important enzymes of human body. Acta Medica (Hradec Kralove). 2004; 47(4): 215-228.

[42] Bradford MM. A rapid and sensitive method for the quatitation of microgram quantities of protein utilizing the principle of protein-dye binding. Anal Biochem. 1976; 72: 248-254. [CrossRef]

[43] Ellman GL, Courtney KD, Andres V, Featherstone RM. A new and rapid colorimetric determination of acetylcholinesterase activity. Biochem Pharmacol. 1961; 7: 88-95. [CrossRef]

[44] Laemmli UK. Cleavage of structural proteins during the assembly of the head bacteriophage T4. Nature (Lond.). 1970; 227: 680-685. [CrossRef] 